\title{
Facile Conversion of Epoxides to Thiiranes with Ammonium Thiocyanate Catalyzed with Etidronic Acid
}

\author{
Liqiang Wu, ${ }^{*}$ Yongxue Wang, ${ }^{\dagger}$ Fulin Yan, and Chunguang Yang
}

\author{
School of Pharmacy, Xinxiang Medical University, Xinxiang, Henan 453003, P. R. China. *E-mail: wliq1974@sohu.com \\ ${ }^{\dagger}$ Department of Life Sciences and Technology, Xinxiang Medical University, Xinxiang, Henan 453003, P. R. China \\ Received October 14, 2009, Accepted March 24, 2010
}

Key Words: Thiiranes, Oxiranes, Etidronic acid

Thiiranes are frequently used in the pharmaceutical, polymer, pesticide, and herbicide industries. ${ }^{1}$ Particularly, thiiranes have played an important role in various synthetic transformations. ${ }^{2}$ Various methods have been developed for the preparation of these compounds. The most common and important method is the transformation of oxiranes into thiiranes with thiourea, ${ }^{3}$ inorganic thiocyanates, ${ }^{4}$ Dowex-50WX8-supported thiourea, ${ }^{5}$ polymer-supported thiocyanates. ${ }^{6}$ Along with each sulfurated reagent, a protic acid such as $\mathrm{Mg}\left(\mathrm{HSO}_{4}\right)_{2},{ }^{3 \mathrm{~g}}$ oxalic acid, ${ }^{4 \mathrm{k}} \mathrm{SiO}_{2-}$ $\mathrm{HBF}_{4}{ }^{4 \mathrm{~d}}$ or a Lewis acid such as $\mathrm{NH}_{4} \mathrm{Cl},{ }^{3 \mathrm{a}} \mathrm{Al}(\mathrm{DS})_{3} \cdot 3 \mathrm{H}_{2} \mathrm{O}$, ${ }^{3 \mathrm{~b}}$ $\mathrm{SiO}_{2}-\mathrm{AlCl}_{3},{ }^{3 \mathrm{c}} \mathrm{LiBF}_{4},{ }^{3 \mathrm{~h}} \mathrm{RuCl}_{3},{ }^{3 \mathrm{i}} \mathrm{SbCl}_{3},{ }^{3 \mathrm{j}}$ Montmorillonite $\mathrm{K}-10,{ }^{3 \mathrm{k}}$ $\mathrm{I}_{2},{ }^{4 \mathrm{a}} \mathrm{LiClO}_{4},{ }^{4 \mathrm{~b}} \mathrm{Sn}^{\mathrm{IV}}(\mathrm{TPP})\left(\mathrm{BF}_{4}\right)_{2},{ }^{4 \mathrm{c}} 2,4,6$-Trichloro-1,3,5-triazine, ${ }^{4 \mathrm{f}}$ $\mathrm{TiO}_{2},{ }^{4 \mathrm{~g}} \mathrm{Sn}^{\mathrm{IV}}$ (TPP)(OTf $)_{2},{ }^{4 \mathrm{~h}} \mathrm{InBr}_{3},{ }^{4 \mathrm{l}} \mathrm{Bi}(\mathrm{TFA})_{3}{ }^{4 \mathrm{~m}} \mathrm{Bi}(\mathrm{OTf})_{3},{ }^{4 \mathrm{~m}}$ $\mathrm{BiCl}_{3},{ }^{4 \mathrm{n}} \mathrm{TiO}\left(\mathrm{CF}_{3} \mathrm{CO}_{2}\right)_{2}{ }^{4 \mathrm{o}}$ and $\mathrm{TiCl}_{3}\left(\mathrm{CF}_{3} \mathrm{SO}_{3}\right)^{4 \mathrm{o}}$ is employed. Recently, ionic liquid ${ }^{7}$ and $\mathrm{MW}$ irradiation ${ }^{8}$ have also been applied to the conversion of oxiranes into thiiranes. Nevertheless, most of these methods suffer one or more of the following drawbacks: unsatisfactory yield, long reaction time, critical product isolation procedures, the use of expensive and detrimental metal precursors, harsh reaction conditions, and no agreement with the green chemistry protocols, which limit their use.

Etidronic acid (Figure 1) is a phosphonic acid with mild acidity, is non-volatile and non-corrosive, and is soluble in common organic solvents. It is a white crystalline solid with outstanding physical and chemical properties and is a commercially available cheap chemical. Its applications as a reaction catalyst in organic syntheses have not yet been fully explored. In this paper, we report a simple and efficient synthesis of thiiranes in THF using etidronic acid as a catalyst (Scheme 1).

Initially, we carried out the reaction of styrene oxide with ammonium thiocyanate in THF in the presence of different amounts of etidronic acid at reflux temperature. It was found that the best result was obtained with $10 \mathrm{~mol} \%$ of etidronic acid.

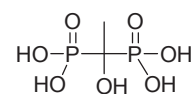

Figure 1. Etidronic acid.

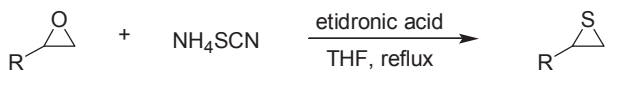

$$
\begin{aligned}
& 12
\end{aligned}
$$

Scheme 1
It is worthy to note that in the absence of etidronic acid, the reaction did not yield any product at reflux temperature even after a long reaction time.

To select the best solvent for the reaction, the synthesis of thiirane 3a was examined in different solvents (Table 2). As Table 2 indicates, higher yields and shorter reaction times were obtained when the reaction was carried out in THF. Thus, THF was used as reaction media for all reactions.

Based on the optimized reaction conditions, a range of thiiranes was synthesized by the reaction of oxiranes $(1,1 \mathrm{mmol})$ with ammonium thiocyanate $(2,1.2 \mathrm{mmol})$ in THF. The reaction proceeded at reflux temperature within $1 \mathrm{~h}$ in excellent yields after the addition of the catalyst etidronic acid $(0.1 \mathrm{mmol})$ (see Table 3). In these experiments, different types of oxiranes such as aliphatic and bicyclic oxiranes underwent the conversion smoothly.

In summary, we have described a simple and highly efficient protocol for the preparation of thiiranes through the reaction between epoxides and ammonium thiocyanate using etidronic acid as a catalyst. The attractive features of this process are mild reaction conditions, inexpensive reagents, short reaction times,

Table 1. The amounts of catalyst optimization for synthesis of 2-phenylthiirane $^{a}$

\begin{tabular}{cccc}
\hline Entry & Etidronic acid $(\mathrm{mol} \%)$ & Time $(\mathrm{min})$ & Yield $(\%)^{b}$ \\
\hline 1 & 0 & 600 & 0 \\
2 & 5 & 60 & 69 \\
3 & 10 & 45 & 95 \\
4 & 15 & 45 & 93 \\
5 & 20 & 45 & 94 \\
\hline
\end{tabular}

${ }^{a}$ Reaction conditions: styrene oxide ( $\left.1 \mathrm{mmol}\right)$; ammonium thiocyanate (1.2 mmol); THF; reflux. ${ }^{b}$ Isolated yield.

Table 2. Solvent optimization for synthesis of 2-phenylthiirane ${ }^{a}$

\begin{tabular}{ccccc}
\hline Entry & Solvent & Temp. $\left({ }^{\circ} \mathrm{C}\right)$ & Time $(\mathrm{min})$ & Yield $(\%)^{b}$ \\
\hline 1 & neat & 60 & 60 & 68 \\
2 & $\mathrm{CH}_{3} \mathrm{CN}$ & 60 & 45 & 76 \\
3 & $\mathrm{EtOH}$ & 60 & 60 & 69 \\
4 & $\mathrm{THF}$ & reflux & 45 & 95 \\
5 & $\mathrm{CH}_{2} \mathrm{Cl}_{2}$ & reflux & 45 & 73 \\
\hline${ }^{a}$ Reaction conditions: styrene oxide $(1 \mathrm{mmol}) ;$ ammonium thiocyanate
\end{tabular}

$(1.2 \mathrm{mmol})$; etidronic acid $(0.1 \mathrm{mmol}) .{ }^{b}$ Isolated yield. 
Table 3. Etidronic acid catalyzed conversion of epoxides to thiiranes at reflux temperature

Eside

${ }^{a}$ Reaction conditions: oxirane $(1 \mathrm{mmol})$; ammonium thiocyanate $(1.2$ mmol); etidronic acid (0.1 mmol); THF; reflux. ${ }^{b}$ Isolated yield.

and cleaner reactions with improved yields, which make it a useful process for the synthesis of thiiranes.

\section{Experimental Section}

To a stirred solution epoxide ( $1 \mathrm{mmol})$ in THF $(5 \mathrm{~mL})$, ammonium thiocyanate $(1.2 \mathrm{mmol})$ and etidronic acid $(0.1 \mathrm{mmol})$ was added and the mixture was stirred at reflux temperature for the specified time (Table 3). After completion of the reaction (TLC), the reaction mixture was diluted with water $(10 \mathrm{~mL})$ and extracted with diethyl ether $(3 \times 10 \mathrm{~mL})$. The combined organic layers were dried over anhydrous $\mathrm{Na}_{2} \mathrm{SO}_{4}$. The solvent was evaporated and the crude product purified by column chromatography (petroleum ether : ethyl acetate $=9: 1$ ) to afford the pure product 3. All products were characterized by comparison of their physical data and ${ }^{1} \mathrm{H}$ NMR, ${ }^{13} \mathrm{C}$ NMR data with those of authentic samples. The spectral data of some new thiiranes are given below.

2-((4-Iodophenoxy)methyl)thiirane (3f). Oil, ${ }^{1} \mathrm{H}$ NMR (CD $\left.\mathrm{Cl}_{3}, 400 \mathrm{MHz}\right) \delta$ 7.20-6.79 (m, 4H, ArH), 4.10-3.90 (m, 2H,
$\left.\mathrm{OCH}_{2}\right), 3.26-3.22(\mathrm{~m}, 1 \mathrm{H}, \mathrm{CH}), 2.55-2.26\left(\mathrm{~m}, 2 \mathrm{H}, \mathrm{CH}_{2} \mathrm{~S}\right) .{ }^{13} \mathrm{C}$ $\mathrm{NMR}\left(\mathrm{CDCl}_{3}, 100 \mathrm{MHz}\right) \delta 155.4,130.1,124.9,117.6,74.8$, 32.2, 22.8. Anal. calcd for $\mathrm{C}_{9} \mathrm{H}_{9} \mathrm{IOS}$ : C 37.00, H 3.11, S 10.98; found C 37.18, H 3.02, S 11.09.

2-(4-Fluorophenyl)-3-phenylthiirane (3k). Oil, ${ }^{1} \mathrm{H}$ NMR (CD $\left.\mathrm{Cl}_{3}, 400 \mathrm{MHz}\right) \delta 7.70(\mathrm{~d}, J=8.4 \mathrm{~Hz}, 2 \mathrm{H}, \mathrm{ArH}), 7.58(\mathrm{~d}, J=8.4$ $\mathrm{Hz}, 2 \mathrm{H}, \mathrm{ArH}), 7.26-7.18$ (m, 5H, ArH), $2.71(\mathrm{~d}, J=7.2 \mathrm{~Hz}, 1 \mathrm{H}$, $\mathrm{CH}), 2.42$ (d, $J=7.2 \mathrm{~Hz}, 1 \mathrm{H}, \mathrm{CH}) .{ }^{13} \mathrm{C} \mathrm{NMR}\left(\mathrm{CDCl}_{3}, 100 \mathrm{MHz}\right)$ $\delta 159.6,138.2,135.2,130.8,130.7,128.5,128.3,125.9,115.6$, 115.5, 45.6. Anal. calcd for $\mathrm{C}_{14} \mathrm{H}_{11} \mathrm{FS}: \mathrm{C} 73.01, \mathrm{H} 4.81$, S 13.92; found C 73.14, H 4.96, S 13.76 .

Acknowledgments. We are pleased to acknowledge the financial support from Xinxiang Medical University.

\section{Reference}

1. Ditter, D. C.; Katritzky, A. R.; Rees, C. W. In Thiiranes and Thiiranes in Comprehensive Hetrocyclic Chemistry; Pergamon: NewYork, 1984; Vol. 7, pp 132-182.

2. Iranpoor, N.; Tamami, B.; Niknam, K. Can. J. Chem. 1997, 75, 1913.

3. (a) Zeynizadeh, B.; Yeghaneh, S. Phosphorus, Sulfur Silicon Relat. Elem. 2008, 183, 2280. (b) Firouzabadi, H.; Iranpoor, N.; Khoshnood, A. J. Mol. Catal. A: Chem. 2007, 274, 109. (c) Parvanak Borujeni, K. Synth. Commun. 2005, 35, 2575. (d) Iranpoor, N.; Firouzabadi, H.; Jafari, A. Phosphorus, Sulfur Silicon Relat. Elem. 2005, 180, 1809. (e) Kiasat, A.; Kazemi, F.; Jardi, M. Phosphorus, Sulfur Silicon Relat. Elem. 2004, 179, 1841. (f) Surendra, K.; Krishnaveni, N. S.; Rao, K. R. Tetrahedron Lett. 2004, 45, 6523. (g) Salehi, P.; Khodaei, M. M.; Zolfigol, M. A.; Keyvan, A. Synth. Commun. 2003, 33, 3041. (h) Kazemi, F.; Kiasat, A. R.; Ebrahimi, S. Synth. Commun. 2003, 33, 595. (i) Kazemi, F.; Kiasat, A. R.; Ebrahimi, S. Phosphorus, Sulfur Silicon Relat. Elem. 2001, 176, 135. (j) Mohammadpoor-Baltork, I.; Khosropoor, A. R. Asian Chem. Lett. 1998, 2, 123. (k) Mohammadpoor-Baltork, I.; Aliyan, H. J. Chem. Res., (S) 2000, 122.

4. (a) Yadav, J. S.; Reddy, B. V. S.; Sengupta, S.; Gupta, M. K.; Baishya, G.; Harshavardhana, S. J.; Dash, U. Monatsh. Chem. 2008, 139, 1363. (b) Reddy, C. S.; Nagavani, S. Hetero. Chem. 2008, 19, 97. (c) Moghadam, M.; Tangestaninejad, S.; Mirkhani, V.; Mohammadpoor-Baltork, I.; Taghavi, S. A. Catal. Commun. 2007, 8, 2087. (d) Bandgar, B. P.; Patil, A. V.; Kamble, V. T.; Totre, J. V.J. Mol. Catal. A: Chem. 2007, 273, 114. (e) Das, B.; Reddy, V. S.; Krishnaiah, M. Tetrahedron Lett. 2006, 47, 8471. (f) Bandgar, B. P.; Joshi, N. S.; Kamble, V. T. Tetrahedron Lett. 2006, 47, 4775. (g) Yadollahi, B.; Tangestaninejad, S.; Habibi, M. H. Synth. Commun. 2004, 34, 2823. (h) Moghadam, M.; Tangestaninejad, S.; Mirkhani, V.; Shaibani, R. Tetrahedron 2004, 60, 6105. (i) Krishnaveni, N. S.; Surendra, K.; Reddy, M. S.; Nageswar, Y. V. D.; Rama Rao, K. Adv. Synth. Catal. 2004, 346, 395. (j) Tamami, B.; Kolahdoozan, M. Tetrahedron Lett. 2004, 45, 1535. (k) Kazemi, F.; Kiasat, A. R. Phosphorus, Sulfur Silicon Relat. Elem. 2003, 178, 1333. (1) Yadav, J. S.; Reddy, B. V. S.; Baishya, G. Synlett 2003, 396. (m) Mohammadpoor-Baltork, I.; Khosropour, A. R. Molecules 2001, 6, 996. (n) Mohammadpoor-Baltork, I.; Aliyan, H. Synth. Commun. 1998, 28, 3943. (o) Iranpoor, N.; Zeynizadeh, B. Synth. Commun. 1998, 28, 3913. (p) Iranpoor, N.; Kazemi, F. Synthesis 1996, 821.

5. Zeynizadeh, B.; Yeghaneh, S. Phosphorus, Sulfur Silicon Relat. Elem. 2009, 184, 362.

6. Tamami, B.; Kiasat, A. R. Synth. Commun. 1996, 26, 3953.

7. Yadav, J. S.; Reddy, B. V. S.; Reddy, C. S.; Rajasekhar, K. J. Org. Chem. 2003, 68, 2525.

8. Kaboudin, B.; Norouzi, H. Synthesis 2004, 2035.

9. Dixon, L. A. In Encyclopedia of Reagents for Organic Synthesis; Paquette, L., Ed.; Wiley: Chichester, 1995; Vol. 6, pp 4166-4169. 